Walisongo Law Review (Walrev), Vol 3 No. 1 (2021)

DOI: 10.21580/walrev/2021.3.1.7282

Copyright (C) 2021 Walisongo Law Review (Walrev)

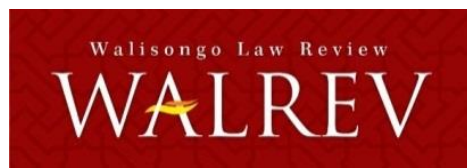

\title{
Institutions and Contributions to Islamic Law in Indonesia's Legal System
}

\author{
Abu Rokhmad \\ Afiliation: Universitas Islam Negeri (UIN) Walisongo, Semarang \\ Email:aburokhmad@walisongo.ac.id
}

\begin{abstract}
This research examines the institutionalization, position and contribution of Islamic law to the national legal system. This study uses a qualitative method with a sociological legal approach. The data source comes from legal materials such as laws and other regulations. The research results show that the institutionalization of Islamic law into the national legal system is carried out procedurally, democratically and in accordance with the needs of the community. This institutionalization is a further process and recognition of the position of Islamic law, not only as a raw material for the making of national laws, but also as a source of law (legal sources) and even a source of values (values sources) for the development of national law. The contribution of Islamic law to the development of the national legal system can be seen in the law on marriage, zakat, waqf, hajj, guarantees of halal products and others which substantively do not contradict Islamic law.
\end{abstract}

[]

Riset ini mengkaji tentang pelembagaan, posisi dan kontribusi hukum Islam ke dalam sistem hukum nasional. Kajian ini menggunakan metode kualitatif dengan pendekatan sosiologi hukum. Sumber data berasal dari bahan-bahan hukum seperti UU dan regulasi lainnya. Hasil riset menunjukkan bahwa pelembagaan hukum Islam ke dalam sistem hukum nasional dilakukan secara prosedural, demokratis dan sesuai dengan 
kebutuhan masyarakat. Pelembagaan ini merupakan proses lanjut dan pengakuan mengenai posisi hukum Islam, bukan saja sebagai bahan mentah (raw material) pembuatan hukum nasional, tapi juga sebagai sumber hukum (legal sources) dan bahkan sumber nilai (values sources) pembangunan hukum nasional. Kontribusi hukum Islam dalam pembangunan sistem hukum nasional dapat dilihat pada UU perkawinan, zakat, wakaf, haji, jaminan produk halal dan lainnya yang secara substantif tidak bertentangan dengan hukum Islam.

Keywords: institutionalization; formalization; contribution; Islamic law; national law.

\section{Introduction}

Studying the law is not just studying the sound of the articles in the law. In essence, studying the law also examines the art of how the human constellation organizes their lives so that peace and justice can be realized. In fact, studying the law also examines the soul of the nation which is reflected in, among other things, the substance of the law, the process of making and enforcing the law, including its legal structure and culture. How a nation is ruled greatly affects the progress and failure of a country. Therefore, according to Niccolo Machiavelli, a successful state administration is largely determined by-one of them-good laws (Kusumohamidjojo, 2004: 63).

The Indonesian people have a unique legal experience. Several legal systems have been, are, and may continue to be practiced in regulating the life of the Indonesian people, even though there are new modern and positive laws. Customary law which became known as customary law (adat recht) (Wulansari dan Gunarsa 2016) has long been a living law and regulates people's lives. Although the use of the term customary law has been criticized, among others by Hidjazie, this law has become an important part of the process of developing national law (Wiranata 2005:4).

After the Indonesian people recognized Islam and more and more people embraced this religion, Islamic law became a living law in society. 
For a Muslim, Islamic law is believed to regulate almost all aspects of life, and not only life in this world but also life after death. After becoming a Muslim, someone who previously followed the practice of customary inheritance, then switched to following Islamic inheritance, although gradually. When compared with customary law, the penetration of Islamic law into people's lives is deeper because it is supported by the power of the Islamic kingdom. When the VOC (Vereenigde Oostindische Compagnie)-a Dutch trading company with state-like authority-was present, Islamic family law, marriage law and inheritance law were recognized and regulated in 1760 Resolutie der Indische Regeering known as the Compendium Friejer. Islamic law that had been in effect during the VOC period was legalized by the Dutch East Indies government in the Regeeringsregrement 1855 (Suny 2017). Despite experiencing dynamics and struggles (Lukito 1998), customary law and Islamic law have enriched the legal experience of the Indonesian nation.

In the next stage, the Indonesian people recognized the new legal system as the influence of Dutch colonialism for \pm 350 years. This European legal system dominates the legal life of the Indonesian people, leaving little role for Islamic law and customary law. Once Indonesia became independent, questions arose from the Indonesian people themselves regarding what law was appropriate to apply to the Indonesian nation based on Pancasila. The choice of law agreed upon by the Indonesian people was not to apply customary law, or religious law (Islam), or colonial law (Europe), for various reasons. The term national law emerged, which is also not easy to explain and refer to in what form. The agreed definition states that national law is the law that comes from three sources, namely modern law or western law (the Netherlands), customary or customary law and Islamic religious law (Azizy 2004:3).

Studying Islamic law in the context of national law is indeed very sensitive. There is one party that wants to replace national law with Islamic law, either completely or partially. Efforts to replace the state basis of Pancasila with the basis of an Islamic state have always appeared to this day, both openly and covertly (Rokhmad 2017). On the other hand, there are also those who are allergic to Islamic law. The application of Islamic law in the national legal system is seen as the Islamization of national law, considering that Indonesia is a multicultural country. In 
fact, Islamic law is clearly practiced by Muslims who make up the majority population in this country.

This article examines the institutionalization process and contribution of Islamic law in the national legal system. This study is very important to do to bridge the views of community groups (Islamic groups and nationalist groups) who are mutually suspicious and do not trust each other. For Islamic groups, Islamic law must be formally practiced in Indonesia. For the nationalist group, the formalization of Islamic law is the Islamization of a state based on the Pancasila philosophy. This article also confirms Pancasila as the basic law chosen by the founding fathers as the best choice capable of accommodating and providing an umbrella for the various different legal choices adopted by the Indonesian people.

\section{Discussion}

\section{Characteristics of National Law}

Law is a summary term to describe a complex set of principles, norms, ideas, rules, customs, and for the activities of the state apparatus relating to legislation, which is supported by political power and legitimacy.

The complex law is condensed into one term, abstracted from the social context in which it exists, and is spoken of as if it were a unit capable of controlling that social context. But the opposite could be the case where society determines the law and not the other way around (Cochrane 1971:93-94). Law as a product of society is understood as a law that reflects the awareness of the whole community (Kusumah dan Baut 1988:95).

Besides the order of morality, customs and religion, the legal order is one (and not the only) order that deals with the universe of order (Rahardjo 2006:95-106). With advantages that other orders do not have, the law has occupied a central position as the guardian, regulator, and producer of order. The legal order is aimed at the perpetrators of violations (actions) that are concrete and not to those who are 
internalized (principle of cogitationis poenam nemo patitur / no one can be punished for what he thinks or thinks). Because of the legal order/rules, the concrete event becomes a legal event.

The law that applies in Indonesia is called national law or positive law. As a result of the 350 years of Dutch colonialism, this national law was heavily influenced by Dutch law. The applicable legal system follows the civil law system. In a broad context, this influence is not only from Dutch law but also Western law as external law. This national law that applies in Indonesia follows the type of modern law (Rahardjo 2000:215-22), which is a type of law that emerged and was formed in connection with the birth of the modern state (Rahardjo dan Dimyati 2002:38). Following the pattern of rationally drafting a modern state, modern law is also built as a rational institution. Ways of making law and administering law are done rationally, even changing the way of thinking and methodology. Modern law changes a social legal order that is more sociological, anthropological, and natural into an artificial and distinct institution (Rahardjo 2006:34).

Western legal systems tend to be liberal-individualistic (respect individual freedom). This is natural considering that it was born from the womb of a feudal-communal society (Gunaryo 2005; Rahardjo 2000:215-16). This legal system takes the form of a formal, established procedure and bureaucracy. Legal material is formulated in a measurable, formal manner and new concepts and special constructions are also created. Not everyone can become a legal operator, but those who have special qualifications and undergo certain formal education. Since then, people can no longer fight for the truth, rights, and so on unless channeled into modern legal channels.

The characteristics of the modern legal system, stated by Marc Galanter (Dimyati 2004:84) include; a) uniform law; consists of regulations that are uniform and do not differ in their application; b) bureaucratic; the system applies according to written procedures for each case and decides each case with written regulations; c) rational; rules and procedures can be ascertained from written sources in ways that can be learned. 
Rahardjo characterizes modern law with three characteristics. First, it has a written form; Second, the law applies to the entire territory of the State; and Third, the law is an instrument that is used consciously to realize people's political decisions (Rahardjo 2000: 214). Unger details the characteristics of modern law, namely a) public; b) positive, c) general; and autonomous. Therefore, Unger (1977: 52-3) calls modern law the legal order or the real legal system (the legal order or the legal system).

Unger asserted that modern law emerged in the context of a liberal society. Modern law is transformed into a rule of law based on individualism that glorifies liberalism (Turkel 1996:47). It is the result of the people's movement in Europe in obtaining freedom and independence from the oppression of the nobility, rulers, and class. Thus, the concept of the rule of law is rooted in the recognition of individual freedom and security which is achieved through social arrangements regarding the limitation of state power, legal equality, and economic rights (rule of law is rooted in the recognition that individual freedom and security are accomplished through a society governed on the basis of legal limitations on state power, legal equality and economic rights).

The rule of law has its history which does not have to be efficaciously practiced in any country. Because every country has a different 'disease' of fate and way of life, it is impossible for the rule of law to be positioned as a panacea drug that is suitable for all diseases for everyone. Indonesia also has its disease and character in law. Unfortunately, the empirical level shows that the development of Indonesian law leads to European legal patterns, especially the Dutch.

The inherent thing that is always attributed to modern law is its positivistic nature. Positivism which was originally used in natural science studies, since the 19th century has grown and spans all domains of science, including law. Positivism and modern law go hand in hand and become an integral part of the project to organize a rational society. Since then, law has become a distinct type of institution, both in substance, methodology and administration. In terms of substance, for example, law relies on regulations that it produces itself, namely legislated rules. There are no other regulations in society except those 
produced by legal institutions (Harun 2019; Rahardjo 2006:27). Legitimate regulations form a world of its own and the working system must be obeyed by every citizen.

The practice of law in Indonesia, especially since the New Order era, shows a situation that is strongly influenced by legal positivism, even legal positivism (legism). In the positivistic view, the law is only what is explicitly stated in the legal rules (laws). What is manifested in practice is only a formal rule of law, which distances the law from justice. When the reform era took place (1998), although legal positivism was still very pronounced, the law was more autonomous and within certain limits independent of government intervention (Nonet dan Selznick 2007).

The development of a better national law is still an important agenda that is carried out, both in terms of substance, structure and legal culture. In that effort, Islamic law as a living law in society needs to be considered. This is not only because the majority of the Indonesian population embraces Islam, but also involves making laws that are following the social basis of society. Of course, the national legal framework based on Pancasila will not be abandoned.

\section{Characteristics of Islamic Law}

Islamic law (Islamic jurisprudence) is the heart and core of the Islamic religion. It is an arena in which the conditions, dynamics and meaning of the relationship between God and man are explored (Abou El Fadl 2014:10). Of the various existing religious sciences (Islam), Islamic law (fiqh) is considered the most important and most intensively studied knowledge of Muslims (Rokhmad 2015:1). Islamic law dominates the way Muslims view everything.

The orthodox theory (salaf) states that every Muslim's life is governed by two kinds of knowledge at once, namely the science of kalam (theology) and the science of fiqh (Islamic law) (Anderson 1994:21). The first concerns what Muslims should believe in their lives. This study is called the science of aqidah (ushuluddin). Second, the study of what Muslims should do in their lives. Knowledge of this developed into (at least according to layman's view) 'science of the Shari'ah', a science that discusses religious laws (Syarifuddin 1997:ix). A good understanding of 
the concepts of Islamic law, Islamic law, fiqh and qanun can reduce errors that often occur.

Etymologically, shari'ah means a drinking place (a place to drink), or an approach to a water hole (closer to a water hole) (Wehr 1979:466). Nabhan defines shari'a linguistically as "the way from which drinking water flows out" (Al-Nabhân 1981:10). According to Syaltout, Shari'a is "al-maurid taummuhu al-nas aw al-dawab li al-syurb" (a place visited by humans and animals to drink water) (Ash-Shiddieqy 1993:31). The way where the water comes out is connoted by the Arabs as a straight path that must be followed (Al-Qaththân 2006:14). For living things, water is a basic need that must be met. Shari'ah and water have the same characteristics, which are cooling, cooling, quenching thirst, and cleansing someone's body.

Shari'ah is understood in various ways by experts but has one meaning in common. Syaltout argues, sharia is a regulation set by Allah SWT or the basics set by Allah so that humans hold fast to it in their relationship with God, fellow Muslims, fellow humans, the universe, and with life (Mahmud 1966:12). According to al-Qaththan, shari'ah is a provision of Allah SWT that is prescribed for His servants, both faith, worship, morals, and mu'amalah (Al-Qaththân 2006:15). Shari'a according to Salam Madkur is the straight path used by jurists to name the laws of Allah SWT which are set for His servants and which are revealed through the intercession of His Messenger to be known with full faith, both concerning deeds, aqidah, and morals. From some of the definitions above, it can be seen that shari'ah is understood differently by scholars.

First, shari'ah is identical to religion (Islam). Such a conclusion is not wrong because the Shari'ah is religion itself. Islamic Shari'ah means all the provisions of the Islamic religion that must be followed, both regarding faith, worship, and mu'amalah. This is also corroborated by the words of Allah SWT in surah al-Maidah (5): 48, al-Shura (42): 13, and alJatsiyah (45): 18 which means "a clear path that leads to victory."

Second, although initially synonymous with religion, then Shari'a is devoted to 'amaliyyah law only. The issue of worship and creed has been explained in detail by Allah SWT and Rasulullah SAW - and specifically 
studied in the science of ushuluddin. This specialization is to distinguish between religion and Shari'ah. In essence, religion is one and applies universally, while the Shari'ah differs from one community to another. Even Qatadah explained the special sharia relates to obligations, legal sanctions, orders, and prohibitions. It does not include aqidah, wisdom, and parables included in religion into the Shari'ah (Djamil 1997:8).

Third, the word shari'ah is used to indicate Islamic laws, both those that are directly stipulated by the Qur'an and al-Sunnah or those that have been interfered with by the thought of scholars (ijtihad). If combined with the results of the ijtihad of scholars, then the shari'ah has narrowed to fiqh. In lughawi, fiqh means "knowing something and understanding it well." Surah al-Taubah verse 122, especially the snippet of the verse liyatafaqqahu $f i$ al-din (to deepen religion) is often used as an argument in interpreting al-fiqh as al-fahm or al-ilm. According to Zahrah, fiqh means deep understanding to find out the purpose of a word or deed" (Zahrah 2005:3). Rashid Rida defines fiqh as al-fahm al-daqiq li al-haqaiq alladzi yakunu bihi al-'alim hakiman 'amilan mutqinan (deep understanding [by knowing fiqh] the pious become perfect and tough judges)" (Ash-Shiddieqy 1993:35).

In terms, according to Abu Hanifah (Nyazee 1994:21), fiqh is ma'rifat al-nafsi ma laha wama 'alaiha (one's self-knowledge about what are their rights and obligations). Ibn Subki, a scholar of the Shafi'iyyah school, defines fiqh as al-ilm bi al-ahkam al-syar'iyyah al'amaliyyah al-muktasab min fairtraina al-tafshiliyyah (the knowledge of the shari'a laws related to deeds). practice] which is explored in detail (Musa 1989:107). According to Al-Syirazi, fiqh is "ma'rifat al-ahkam alsyar'iyyah allati thariquha al-ijtihad" (knowing the law of syara' where the way is by ijtihad) (Al-Shirazi 1990:4).

From the above understanding, fiqh is not sharia but an interpretation of sharia law. Therefore, the character of fiqh is a). Knowledge of sharia law'; b). Studying things that are 'amaliyyah furu'iyyah (deeds of mukallaf and branch); c). Knowledge of syara' law is based on tafsili arguments, namely the Qur'an and Hadith; d). Fiqh is excavated and found through mujtahid's istidlal reasoning; e). Fiqh is a 
strong conjecture (dzanny) achieved by a mujtahid in his quest to find Allah's law.

People are also familiar with the term Islamic law. This term has become Indonesian. The Qur'an only mentions the word shari'ah, fiqh, Allah's law (hukm Allah), and the same root with it. Islamic law is a translation of the term Islamic Law in Western literature. As shown by Joseph Schacht, that Islamic law is the entire book of Allah SWT which regulates Muslim human life in all its aspects (Schach 1982:1). Islamic law which he means is close to Islamic law.

Islamic law is not only a legal system originating from the din (religion or sharia) of Islam but also the law that is integral to the Islamic religion (law is integral to Islamic religion) (Vago 2015:44). Bustanul Arifin is of the view that Islamic law is part of Shari'ah, while Shari'a is an implementation of al-din (Islamic religion) (Arifin 1996:25). According to Azizy, after becoming a separate discipline, the term fiqh or often called Islamic fiqh is usually defined by Islamic law or some call it positive Islamic law (Azizy 2004). In the latter case (positive Islamic law), it refers more to Islamic law that has been 'formalized' by the State, for example, the Law on zakat management, the Waqf Law, the Hajj Law, and so on.

Although fiqh is usually defined by Islamic law, the law here is not always synonymous with rules or legislation. The law which includes alahkam al-khamsah (five laws in fiqh) is closer to the concept of religious ethics (Djamil 1997:37-38). Daud Ali defines Islamic law as the law that originates and becomes part of the Islamic religion (Ali 2012:45). Hasbi ash-Shiddieqy defines Islamic law as a collection of fuqaha's efforts in implementing Islamic law by the needs of the community (Ash-Shiddieqy 1993:21; Mubarok 2000). The three definitions above indicate that Islamic law is identical to the notion of fiqh.

Indonesian people are also familiar with the term qanun, especially in Nanggroe Aceh Darussalam (NAD). Initially, qanun or kanun came from Greek, entered into Arabic through Syriac. Linguistically, Kanun means measuring instrument, and then it means a rule. In European languages, Kanun is used for Church law (Canon Law) (Mahmassani 1976:27). According to Hasbi, the word kanun is now used in several 
meanings, such as (1) code, codex; (2) syara', shari'ah, or jus, law, recht; (3) the rules of mu'amalah, or lex, law, loi gezet (Ash-Shiddieqy 1993:7).

Few fuqaha use this term, and more use the word shari'ah or fiqh. Among the few, Al-Mawardi uses the term qanun in several places in his book al-Ahkam al-Sulthaniyyah, for example qawanin al-siyasah, hifdh al-qawanin al-syar'iyyah wa harasat al-ahkam al-diniyyah or alqawanin al-muqarrah (Azizy 2004:75-76). Abul Qasim ibn Jizzy named his book Al-Qawanin al-Fiqhiyyah fi Talkhis Madzhahib al-Malikiyyah (Ash-Shiddieqy 1993:7). In the Ottoman era, Kanun was often used for the rules made by the state, to distinguish them from the rules of Islamic Shari'ah. Especially in the case that there are differences in legal provisions between Kanun and Shari'ah (Mahmassani 1976:28).

Constitution No. 11 of 2006 concerning the Aceh Government emphasizes the necessity of the birth of another organic law that regulates Islamic Shari'a at the operational level in Aceh called Qanun. Qanun was born through a legislative process in the Aceh People's Representative Council (DPRA), such as Regional Regulations in other regions of Indonesia. This Qanun is the material and formal law of Islamic Shari'ah in Aceh. On this basis, the formalization of Islamic law in Aceh is not only legal but also a demand for the implementation of the Constitution (Bagir et al. 2011:xi).

Based on the above concepts, sharia is different from fiqh, Islamic law, or qanun. Shari'a is interpreted as the law of Allah SWT as stated in the Qur'an and al-Sunnah. Fiqh is the scholars' understanding of the Shari'a (Ali 2012:44). Shari'a is divine, permanent, sacred, and the level of truth is certain (qathiyyat). Meanwhile, fiqh is human, changing, profane, and the level of truth is relative (dhanniyyat), and debatable (Praja 1993:vii). Islamic law and qanun are fiqh that is already formal in the form of the Constitution or regional regulations. Specifically, the qanun only applies in Nangroe Aceh Darussalam.

Islamic law is a living law in society. Muslims consider it a sacred law and regulate all aspects of life (Arfa 2007:1). As a legal system originating from Islam, several characters need to be understood. According to Yusuf Musa, there are 6 (six) characteristics of Islamic law. First, the general basis comes from Allah's revelation (al-Qur'an and al-Hadith). Second, 
the rules of Islamic law are made with religious and moral impetus. Third, the reward will be given in this world and the hereafter. Fourth, the tendency of Islamic law is communal. Fifth, can develop according to the environment, time and place. Sixth, regulate and provide convenience for private and public life and happiness for the whole world (Musa 1988:160-79).

Hasbi Ash-Shiddieqy explained about 4 (four) characteristics of Islamic law, namely humanity, morality, and nature (universal) (AshShiddieqy 1993:157). Yusuf al-Qardhawi mentions 11 (eleven) characteristics of Islamic law, including rabbani (sourced from God), akhlaqi (morality), waquiz (empirical), insani (humanity), tanasuq (regular) and syumul (perfect/comprehensive) (Qardhawi 2008:13). Ahmad Hanafi characterizes 5 (five) characteristics of Islamic law (Hanafi 1984:14). First, the source of the law comes from revelation (alQur'an and al-Hadith). This law is the law of Allah because it is seen as a law that must be true and above all other laws. Second, Islamic law is universal. That is, Islamic law is not only for one particular group but for all nations. Third, Islamic law is humanitarian in nature by paying attention to all affairs (world and the hereafter) and protecting everything related to humans. Fourth, Islamic law is based on morals and not just rules. Fifth, Islamic law is dynamic and always follows changes in society.

Fathurrahman Djamil introduced 5 (five) characters of Islamic law. First, Islamic law was created perfectly by Allah SWT. The law is permanent, although global and not detailed. This trait is intended to give Muslims the freedom to perform ijtihad according to the circumstances and conditions of their time. Second, the character of Islamic law is flexible and flexible (elastic). The law regulates life in the world and the hereafter and pays attention to various aspects: private law, public law, worship including how to purify oneself (thaharah). In its breadth, Islamic law is not rigid, harsh or even coercive. Third, universal and dynamic. Islamic law applies to all nations and peoples, both past and future. Therefore, Islamic law is always suitable for all situations and conditions (shalih li kulli Zaman wa Makan). Fourth, Islamic law has a systematic character. In a sense, Islamic law reflects logically related doctrines. Fifth, ta'aqquli (rational) and ta'abbudi 
(irrational, especially in the field of worship) (Djamil 1997:46-52). The doctrine of Islamic law in the field of muamalah, for example, can all be tested through rational reasoning.

But for matters of worship, fully submit to the provisions of Allah with various hidden wisdom. When compared, the characteristics of national law and Islamic law are very different. National laws are made and compiled based on the power of reason by authorized institutions, do not regulate moral matters and do not promise an afterlife. The law is mundane and profane. The ideal target is to create peace and justice in society, although this often does not materialize. The characteristics of Islamic law are very different from national law. The source of Islamic law comes from God which is summarized in the holy book (al-Qur'an and al-Hadith). Therefore, Islamic law is sacred. All aspects of life in the world are regulated, from the method of purification, marriage law, civil law to criminal law. The purpose of Islamic law is not only for happiness in this world but also for happiness in life in the hereafter.

\section{Institutionalization of Islamic Law}

Historically, the study of the application of Islamic law in Indonesia can be divided into two stages, namely the period of the Dutch East Indies and the period of Indonesian independence (Arifin 1996:73-75). During the Dutch colonial period, the application of Islamic law followed two theories. First, the theory of acceptance of Islamic law in full (receptie in complex theory). All Muslims use the Islamic legal order in their entire life, such as the law of marriage, inheritance and others. The supporter of this theory is a Dutch scholar who has lived in Indonesia for a long time, namely L.W.C. Van Den Berg (1845-1927). Second, Islamic law only applies if it has been accepted by customary law (receptie theory). This theory was initiated by Christian Snouck Hurgronje (18571936) whose point is that Islamic law can be applied if it has become part of customary law. If customary law does not accept it, it means that Islamic law cannot apply. At that time, the Dutch East Indies government legalized the implementation of Islamic law and customary law through the Regeeringsreg in 1855 . 
At the time of Indonesia's independence, after the debate based on the state was over, a third theory emerged that contradicted the receptie theory. This theory is called the receptive exit theory with the stance that the application of Islamic law does not have to be based on or dependent on customary law (Hazairin 1974). Islamic law still applies, even though customary law does not accept it. The fourth theory is called the theory of receptio a contrario which asserts that customary law can only apply if it is of one spirit and does not conflict with Islamic law (Thalib 1980:1517). The above theories explain the struggle between Islamic law and customary law, which is no longer relevant to be discussed at this time.

The theory of existence initiated by Ichtijanto (1991: 137) discusses the issue of the implementation of Islamic law in Indonesia. This theory assumes that the existence of Islamic law is one of the sources of national law. The argument is built on three things. First, Islamic law is an integral part of Indonesian national law. Its existence, independence, power, and authority are recognized by national law and given national legal status. Second, Islamic legal norms serve as a filter for Indonesian national legal materials. Third, Islamic law is the main ingredient and main element of national law.

According to Friedman, in the legal system, three main elements will determine the effectiveness of law enforcement in a country. The three main elements are the legal structure (legal structure), legal substance (legal substance), and legal culture (legal culture) which is a living law in society (Friedman 2011). The formalization of Islamic law in the national legal system of a country can also be studied through this theory. The author calls it a plus legal system theory, with the following explanation.

First, the formalization of Islamic law through a legal structure. The legal structure is the internal structure of the legal system which includes the understanding of the institutional aspects of the legal system, which is related to the process of institutionalizing legal functions and the mechanism of the relationship between institutions and between legal functions, which is a broad sense includes starting from the law and rulemaking function. ), the application of law (the administration of law), to law enforcement and justice (law enforcement) (Ash-Shiddieqy 1993). In the context of Islamic law in Indonesia, the Religious Courts (PA), 
religious judges, and Sharia lawyers, including an aspirational arrangement of legislative bodies towards the legal needs of the community, constitute the structure of Islamic law. Through this legal structure, Islamic law has worked and if there is a dispute, the court will handle it. Although PA still has limited authority (Islamic civil and Islamic economics), but institutionally PA is very strong (Cammack dan Feener 2012).

Second, the formalization of Islamic law through the formulation of legal substance. What is meant by the legal substance are norms, rules, and patterns of community behavior. Even though Indonesia is not an Islamic country, Islamic law has the opportunity to enrich national law and even become part of national law. Through a democratic process, aspects of the interests of Muslims have now been regulated in a separate law, such as the zakat law, waqf law, sharia banking law, and others. The application of Islamic law in terms of legal substance is what is meant by the positivization strategy of Islamic law into the national legal system. This positivization is not a reception-as in the past, but an academically acceptable process (jurisprudence) and democratic (Azizy 2004).

Third, the formalization of Islamic law through legal culture (legal culture). This legal culture is very important and is the foundation of the structure and substance of the law. Culture greatly influences the laws of a nation (Rahardjo 1983). The soul of the nation (volkgeist) is influenced by culture, social and religion. Legal culture concerns values, thoughts, legal awareness and the social atmosphere of the community. There are two kinds of legal culture, namely: internal legal culture, namely the legal culture of citizens who carry out specific legal tasks, such as police, prosecutors, judges and lawyers; and external legal culture, namely the legal culture of society in general (Lev, Nirwono, dan Priyono 1990). This section is closely related to the functions of education, socialization and culture. With this strategy, the question of the formalities of Islamic law becomes less important. What is needed are good habits that are following Islamic law. This cultural strategy almost does not have the slightest resistance because it grows from the legal awareness of the community and does not involve outside political forces.

\section{Implication}


Debates about the position of Islamic law in the national legal system occurred not only in the early days of Indonesian independence but also during the reform era (Hosen 2005; Maarif 1987). In the future, the opportunity for a similar debate is very likely to occur again, considering two things. First, the strengthening of Islamic political sentiment since the 2017 Jakarta Pilkada (Mietzner dan Muhtadi 2018; Setijadi 2017). Second, the strengthening of intolerant Muslim groups and groups supporting the establishment of the Islamic caliphate.

Indonesian legal scholars have always said that Islamic law-along with customary law and Western law-is the raw material for making national laws. In legal research, the basic legal materials are divided into 3 (three) parts (Dimyati 2004). First, primary legal materials, namely materials that have binding power, such as the basic norms of Pancasila, the Constitution, laws and regulations, jurisprudence, treaties, and legal materials that are not codified. Second, secondary legal materials, namely legal materials that do not have the power to remember and only function as an explanation of primary legal materials. Examples include draft laws, books, research, and scientific publications. Third, tertiary legal materials, namely materials that provide information related to primary and secondary legal materials. Atmadja and Budiartha (2018) introduced the term legal sources which mean legal sources (Gede dan Putu 2018). However, this term is still interpreted as legal material, such as legislation and legal decisions.

Based on the view above, it is not wrong to call the position of Islamic law a legal material for the development of national law. Even though Islamic law is based on revelation, its position is the same and no different from customary law or western law made by human reason, namely as the raw material for making national laws. The reason is that Islamic law (fiqh) is the result of the ijtihad of scholars whose truth is relative (dzanni). Islamic law is indeed derived from Islamic Shari'a which is considered sacred but the result of the thought of scholars does not have that characteristic. Therefore, do not be surprised if the views of scholars regarding a particular legal case can vary in law (ikhtilaf) due to different points of view, experience, level of education, and methods of determining Islamic law used. 
On the part of some circles, this position is just as one of the legal materials, it makes Islamic law seem subordinate to national law. National law as the applicable law in Indonesia further strengthens its dominance. Indeed, national law greatly benefits because Islamic law is an abundant legal material and national law does not have to be built from scratch.

There is a more proportional and precise term, which can describe where the position of Islamic law in the national legal system. The term is a source of law (legal sources) or mashadir al-hukm. In the study of Islamic legal theory (ilm al-ushul al-fiqh), this term means the source from which the law originates or the source from which the law is taken (Rokhmad 2015). Based on this concept, the position of Islamic law is a source of national law. From there, national law gets material, values, or legal inspiration that can enrich the substance of national law.

Legal material implies the impression as if legal material is everywhere and scattered, it is already there and just needs to be picked up. There is no difference that the legal material comes from religion, customs, or other sources. Meanwhile, when using the term source of law, legal materials are selected, taken in the right way and process (scientific method), and sourced from the 'wells' of the rules of life that contribute greatly to the creation of peace and justice in society. Religion can be seen as one-if not the only-source of a very deep and abundant source of rules of life, both regulating private and public life.

As one of the sources of national law, Islamic law has contributed significantly in efforts to grow, build and enrich national law. In the field of Islamic family law (HKI/ al-ahwal al-syakhshiyyah), Law Number 1 of 1974 concerning Marriage is a form of positivization of Islamic law into the national legal system. The articles are considered very Islamic in character (Basyir 1983). Equipped with material law in the Compilation of Islamic Law (Presidential Instruction Number 1 of 1991) and UUPA (Law Number 7 of 1989 and its amendments to the Act), the existence of Islamic law and its institutions is very clear in this Pancasila state (Wahyudi 2015). The Religious Courts are the executor of judicial powers that specifically resolve issues of Islamic family law and sharia economics. 
In other civil fields, Indonesia has laws that specifically regulate matters of Muslim interest, such as Law Number 23 of 2011 concerning Zakat Management, Law Number 13 of 2008 concerning the Implementation of the Hajj, and Law Number 41 of 20014 concerning Waqf. Zakat and Hajj are the two pillars (foundations) in Islam. The implementation of zakat requires government intervention because it involves the collection, distribution, and empowerment of very large zakat funds. If it is not regulated, it is feared that zakat collection practices may occur which are contrary to Islamic law and national law. The same applies to the arrangements for Hajj. Hajj is a complex mahdah worship, in which there is a large economic cycle and the mobilization of people from one country to another, so it requires special management.

In the field of economic law, since the birth of Bank Muamalat Indonesia in 1991, Indonesia has experienced a new stream of Islamic economics. Since then, various regulations have been issued to support Sharia economic growth. Starting with the enactment of Law Number 7 of 1992 concerning Banking, which contains rules for the possibility of banking business activities using Sharia principles. Then in 2008, Law Number 21 of 2008 concerning Sharia Banking was enacted. This law explains two important things regarding Sharia principles. First, the socalled Sharia principles are the principles of Islamic law. Second, the party/institution authorized to issue a fatwa that forms the basis for Sharia principles is the National Sharia Council of the Indonesian Ulema Council (DSN-MUI). Based on this regulation, the Financial Services Authority (OJK), Bank Indonesia, and the National Sharia CouncilIndonesian Ulema Council (DSN-MUI) have produced many Bank Indonesia Regulations (PBI) and Financial Services Authority Regulations (POJK) that adapt and harmonize fatwas. DSN-MUI. So it can be said that the absorption of fatwas into official state regulations has been going well in the banking sector. The same thing happened in the insurance, financing, and capital market sectors (Amin 2017). Likewise, Law number 33 of 2014 concerning Halal Product Guarantee is a regulation that wants to protect Muslim consumers from consuming or using non-halal products. 
Indonesia organizes life and life using democratic legal rules. The principles of democracy and law work together to realize the national legal order in the country (Astomo 2016:16). In that principle, the entire process of institutionalizing Islamic law above is carried out democratically. From the initiation stage (ideas raised by the community), the socio-political stage (the sharpening of ideas) to the juridical stage (the preparation of materials into legal formulations and then promulgation) we have gone through a valid, transparent, and participatory mechanism (Rahardjo 2000:178). Of course, both at the initiation stage, discussing the draft law (RUU) to becoming law (UU) there are political dynamics that occur. Political parties that have representatives in the House of Representatives (DPR) review each proposed bill. If they do not agree, they do not hesitate to refuse or walk out of the discussion forum (Ghofur 2014; Kurniawan 2013).

Based on the explanation above, it can be understood that Islamic law has a major influence and contribution to the development of law in Indonesia (Hadi dan Hasan 2015; Imron 2008; Ubaidillah 2008). The substance of Islamic law-in various fields of law-can enrich the building of the national legal system. The existence of a law that specifically regulates the interests of Muslims does not mean that this law is discriminatory. The largest part of the Indonesian population is Muslim, so it is not an exaggeration if their legal needs are also facilitated by the state. Moreover, all laws that regulate the interests of Muslims are also reviewed and formulated according to applicable law. The institutionalization of Islamic law into the national legal system has been carried out democratically and under the legal needs of the local community.

\section{Conclusion}

The institutionalization of Islamic law into the national legal system has taken place democratically (consulted, reviewed, and ratified by the legislature) and in accordance with the needs of the community. The legal needs of Muslims are not the same as the legal needs of adherents of other religions. Therefore, state facilitation in the form of laws that 
specifically regulate the needs of Muslims, such as hajj, zakat, waqf, banking, guarantees for halal products is a form of state protection for people who have different legal needs. The position of Islamic law in the national legal system is very important, not only as a raw material for making national laws but also as sources of law (legal sources) and even sources of value (values sources) for the development of national law.

The institutionalization of Islamic law in Indonesia is a process of formalizing laws containing Islamic teachings into laws through a democratic process. The institutionalization of Islamic law is an advanced process and recognition of the position of Islamic law which is very important for the development of national law. If the position and institutionalization of Islamic law are solid, it means that the contribution of Islamic law to the development of national law is increasingly real. Thus, substantively, more and more national laws are adopting Islamic legal values. [w]

\section{REFERENCES}

Abou El Fadl, Khaled. 2014. Speaking in God's name: Islamic law, authority and women. London: Simon and Schuster.

Al-Nabhân, Muhammad Fârûq. 1981. al-Madkhal li al-Tasyri’al-Islami. Beirût: Dâr alQalam.

Al-Qaththân, Mannâ'. 2006. al-Tasyrïwa al-Fiqh fi al-Islam. Beirut: Muassasah al-Risalah.

Ali, H. Mohammad Daud. 2012. Dalam Hukum Islam di Indonesia. Jakarta: Rajawali Pers.

Amin, Ma'ruf. 2017. "Solusi hukum Islam (makharij fiqhiyyah) sebagai pendorong arus baru ekonomi syariah di Indonesia: kontribusi fatwa DSN-MUI dalam Peraturan Perundang-Undangan RI."

Anderson, J. N. D. 1994. Islamic Law in The Modern World (Hukum Islam di Dunia Modern). Yogyakarta: Tiara Wacana.

Arfa, Faisar Ananda. 2007. Filsafat Hukum Islam. Bandung: Citapustaka Media.

Arifin, Bustanul. 1996. Pelembagaan Hukum Islam di Indonesia: Akar Sejarah, Hambatan dan Prospeknya. Jakarta: Gema Insani Perss. 
Ash-Shiddieqy, M. Hasbi. 1993. Falsafah Hukum Islam. Jakarta: Bulan Bintang.

Astomo, Putera. 2016. "Pembentukan Undang-Undang dalam Rangka Pembaharuan Hukum Nasional Di Era Demokrasi.” Jurnal Konstitusi 11(3):577-99.

Azizy, Ahmad Qodri Abdillah. 2004. Hukum Nasional: Eklektisisme Hukum Islam dan Hukum Umum. Bandung: Teraju.

Bagir, Zainal Abidin, Adzkar Ahsinin, Afridal Dami, Roichatul Aswidah, dan Ifdhal Kasim. 2011. Analisis Qanun-Qanun Aceh Berbasis Hak Asasi Manusia. Jakarta: Indonesian Centre for Democracy and Human Rights.

Basyir, Ahmad Azhar. 1983. Hukum adat bagi ummat Islam. Yogyakarta: Nur Cahaya.

Cammack, Mark E., dan R. Michael Feener. 2012. "The Islamic legal system in Indonesia." Pac. Rim L. \& Pol'y J. 21:13.

Cochrane, Glynn. 1971. Development anthropology. New York: Oxford University Press.

Dimyati, Khudzaifah. 2004. Teorisasi Hukum Studi Tentang Perkembangan Pemikiran Hukum di Indonesia, 1945-1990. Surakarta: MUP.

Djamil, Fathurrahman. 1997. Filsafat Hukum Islam. Jakarta: Logos Wacana Ilmu.

Friedman, Lawrence M. 2011. Sistem Hukum: Perspektif Ilmu Sosial. diedit oleh Khozim. Bandung: Nusa Media.

Gede, Atmadja I. Dewa, dan Budiartha I. Nyoman Putu. 2018. Teori-teori Hukum. Malang: Setara Press Kelompok Intrans Publishing.

Ghofur, Abdul. 2014. Politik Hukum Legislasi UU Perbankan Syariah di Indonesia. Semarang: RaSAIL Media Group.

Gunaryo, Achmad. 2005. Dari Rule of Law Menuju Rule of Social Justice. Semarang.

Hadi, Abdul, dan Shofyan Hasan. 2015. "Pengaruh Hukum Islam Dalam Pengembangan Hukum di Indonesia." Nurani 15(2):89. doi: 10.19109/nurani.v15i2.284.

Hanafi, Ahmad. 1984. Pengantar Sejarah Hukum Islam. Jakarta: PT Bulan Bintang.

Harun, Muhammad. 2019. "Philosophical Study of Hans Kelsen's Thoughts on Law and Satjipto Rahardjo's Ideas on Progressive 
Law." Walisongo Law Review (Walrev) 1(2):195. doi: 10.21580/walrev.2019.1.2.4815.

Hazairin. 1974. Tujuh Serangkai Tentang Hukum. Jakarta: Tintamas.

Hosen, Nadirsyah. 2005. "Shari'a \& Constitutional Reform in Indonesia." Master Thesis, National University of Singapore, Singapore.

Imron, Ali. 2008. "Kontribusi Hukum Islam Terhadap Pembangunan Hukum Nasional (Studi Tentang Konsepsi Taklif dan Masuliyyat dalam Legislasi Hukum).”

Kurniawan, Puji. 2013. "Legislasi Undang-Undang Zakat." Jurnal AlRisalah 13.

Kusumah, Mulyana W., dan Paul S. Baut. 1988. Hukum, politik dan perubahan sosial. Jakarta: Yayasan Lembaga Bantuan Hukum Inodnesia.

Lev, Daniel S., Nirwono, dan A. E. Priyono. 1990. Hukum dan politik di Indonesia: Kesinambungan dan Perubahan. Jakarta: Lembaga Penelitian, Pendidikan dan Penerangan Ekonomi dan Sosial (LP3ES).

Lukito, Ratno. 1998. Pergumulan antara hukum Islam dan adat di Indonesia. Yogyakarta: Inis.

Maarif, Ahmad Syafi'i. 1987. Islam dan Masalah Kenegaraan, Studi tentang Percaturan Dalam Konstituante. Jakarta: LP3ES.

Mahmassani, Subhi. 1976. Filsafat Hukum Dalam Islam. Bandung: PT al-Maarif.

Mahmud, Syaltut. 1966. Al-Islam 'Aqidah wa Syari'ah. Kuwait: Daru alQalam.

Mietzner, Marcus, dan Burhanuddin Muhtadi. 2018. "Explaining the 2016 Islamist mobilisation in Indonesia: Religious intolerance, militant groups and the politics of accommodation." Asian Studies Review 42(3):479-97.

Mubarok, Jaih. 2000. "Sejarah dan Perkembangan Hukum Islam." in Dinamika Hukum Islam. Bandun: Rosda Karya.

Musa, Kamil. 1989. al-Madkhal ila al-Tasyri'al-Islami. Beirut: Mu'assasah al-Risalah.

Musa, Muhammad Yusuf. 1988. Islam Suatu Kajian Komprehensif. Jakarta: Rajawali.

Nonet, Philippe, dan Philip Selznick. 2007. Hukum Responsif. Bandung: Nusa Media. 
Nyazee, Imran Ahsan Khan. 1994. Theories of Islamic law. Pakistan: Islamabad Islamic Research Institute Press.

Praja, Juhaya S. 1993. Filsafat Hukum Islam. Bandung: Yayasan Piara.

Qardhawi, Yusuf. 2008. Legalitas Politik Dinamika Perspektif Nash dan Asy-Syariah. Bandung: Pustaka Setia.

Rahardjo, Satjipto. 1983. Permasalahan Hukum di Indonesia. Bandung: Alumni.

Rahardjo, Satjipto. 200o. Ilmu Hukum. Bandung: Citra Aditya Bakti.

Rahardjo, Satjipto. 2006. Hukum dalam Jagat Ketertiban. Jakarta: Uki Press.

Rahardjo, Satjipto, dan Khudzaifah Dimyati. 2002. Sosiologi hukum: perkembangan, metode, dan pilihan masalah. Muhammadiyah University Press.

Rokhmad, Abu. 2015. Ushul Al-Fiqh. Semarang: Varas.

Rokhmad, Abu. 2017. Islam dan negara: pergulatan ideologis partai politik (berbasis) islam tentang dasar negara di era reformasi. diedit oleh N. Nurdin. Semarang: eLSA Press.

Schach, Joseph. 1982. An Introcution to Islamic Law. New York: Oxford University Press.

Setijadi, Charlotte. 2017. "Ahok's downfall and the rise of Islamist populism in Indonesia." ISEAS Perspective 38(8).

Suny, Ismail. 2017. "Hukum Islam dalam Hukum Nasional." Jurnal Hukum \& Pembangunan 17(4):351-57.

Syarifuddin, Amir. 1997. Ushul Fiqh I. Jakarta: Logos.

Thalib, Sayuti. 1980. Receptio a Contrario: Hubungan Hukum Adat dengan Hukum Islam. Jakarta: Bina Aksara.

Turkel, Gerald. 1996. Law and Society Critical Approaches. New York: Allyn and Bacon.

Ubaidillah, M. Hasan. 2008. "Kontribusi Hukum Islam dalam Mewujudkan Good â€ ŽGovernance di Indonesia." Al-Qanun: Jurnal Pemikiran dan Pembaharuan Hukum Islam 11(1 Juni):11241.

Vago, Steven. 2015. Law and society. New York: Prentice Hall.

Wahyudi, Yudian. 2015. The Position of Islamic Law in the Indonesian Legal System (1900-2003). Yogyakarta: Nawesea Press.

Wehr, Hans. 1979. A Dictionary of Modern Written Arabic. Wesbaden: Otto Harrassowitz Verlag. 
Wiranata, I. Gede A. B. 2005. Hukum Adat Indonesia Perkembangan dari masa ke masa. Bandung: Citra Aditya Bakti.

Wulansari, Catharina Dewi, dan Aep Gunarsa. 2016. Hukum adat Indonesia: suatu pengantar. Bandung: Refika Aditama.

Zahrah, Muhammad Abu. 2005. Ushul al-Fiqh. Jakarta: Pustaka Firdaus. 